\title{
Elemental ratios in sediments as indicators of ecological processes in Spanish reservoirs
}

\author{
P. Lopez ${ }^{1}$, E. Navarro, R. Marce, J. Ordoñez, L. Caputo and J. Armengol \\ Department of Ecology, University of Barcelona, Avda Diagonal 645, Barcelona, SPAIN. \\ ${ }^{1}$ Corresponding author: marilopez@ub.edu
}

\begin{abstract}
Reservoir sediments are important archives of biogeochemical data, reflecting ecological processes that occur at the watershed system. In this paper, a preliminary study of the limnological significance of major element composition and element ratios in sediments of Spanish reservoirs is presented, by analysing two data-sets from different limnological regions. Reservoirs from Eastern and Western Spain present significant differences in the chemical composition of their sediments: higher average values for calcium and magnesium appear in the Eastern reservoirs, while, in Western Spain, higher mean values are found for alumino-silicate elements (i.e. silicon, aluminium, and potassium), iron and phosphorus. Meaningful ratios are $\mathrm{Si} / \mathrm{Al}$ and $\mathrm{Si} / \mathrm{K}$, that are closely related to energy transport in sedimentary catchments, whereas in siliceous catchments $\mathrm{Si} / \mathrm{Al}$ is an indicator of chemical weathering. $\mathrm{Ca} / \mathrm{Al}$ ratio appears related to water mineralization, and, in the Eastern Region, the slope of the regression line between $\mathrm{Ca} / \mathrm{Al}$ and conductivity reflects catchment mineralogy. In superficial sediments from both Eastern and Western regions, Fe/Al is linked to the authigenic precipitation of iron oxides and appears closely related to sedimentary phosphorus accumulation above background levels.
\end{abstract}

Keywords: Elemental composition, major elements, phosphorus, regional limnology.

\section{RESUMEN}

El sedimento de los embalses constituye un importante registro de datos biogeoquímicos, ya que refleja los procesos ecológicos que tienen lugar en el conjunto de la cuenca hidrográfica. A partir del análisis de dos conjuntos de datos obtenidos en distintas regiones limnológicas, se presenta una aproximación preliminar al significado limnológico de la composición química y los cocientes elementales en el sedimento de los embalses españoles. Las regiones Este y Oeste de la Peninsula muestran diferencias significativas en cuanto a composición química del sedimento: los mayores valores promedio en la región Este corresponden a la concentración de calcio y magnesio, mientras que en la región Oeste, los mayores valores medios corresponden a los elementos asociados a los alumino-silicatos (aluminio, silicio y potasio), hierro y fósforo. Los cocientes elementales con mayor significado son: Si/K y Si/Al estrechamente relacionados con la energía de transporte en la región calcárea, mientras que en la región silícica Si/Al es un indicador del proceso de meteorización química. Ca/Al se encuentra asociado a la mineralización del agua, y en la región Este la pendiente de la recta de regresión entre Ca/Al y la conductividad del agua refleja la mineralogía de la cuenca. En ambas regiones, el cociente Fe/Al en el sedimento superficial indica la precipitación endógena de óxidos de hierro y aparece estrechamente asociado a la acumulación de fósforo sedimentario por encima del nivel basal.

Palabras clave: Composición elemental, elementos mayoritarios, fósforo, limnología regional.

\section{INTRODUCTION}

Reservoirs have been the major subject of study in Spanish Limnology over the last decades. Since the first work performed by Margalef and co-workers in the late seventies (Margalef et al., 1976), a high number of studies have dealt with several aspects of reservoir limnology, both as a regional study and as an intensive approach over an specific reservoir or a series of enchained reservoirs. These studies have focussed on ecological features such as hydrodynamics (e.g., Vidal et al., 2005, Rueda et al, 2006), water chemistry (e.g. Armengol et al., 1991, Riera et al., 1992, Pozo et al., 1997), eutrophication (e.g. Riera et al., 1995, Fraile et al., 1995, Boavida \& 
Marques, 1996, Palau, 2003 ), phytoplankton (e.g. Gomez et al., 1995, Dasi et al, 1998), zooplankton (e.g. Jaume, 1991) and bacterial communities (e.g. Simek et al., 1998, 2000).

However, characterization and biogeochemistry of sediments in Spanish reservoirs has received relatively little attention. Issues focussed by studies on reservoir sediments included quantification of sediment transport and accumulation (Diaz et al., 1992, Vericat \& Batalla, 2005, de Vente et al., 2005, Verstraeten et al., 2003), mineral composition (Valero-Garces et al., 1999, Navas et al., 2004), biological communities (e.g. Prat \& Daroca, 1983, Real et al., 1993, 2000), distribution of sedimentary phosphorus along vertical profiles (Armengol et al, 1984, 1986) and at as a regional study (Lopez \& Morgui, 1993), and distribution of grain-size (Morgui et al, 1993); but few studies have reported data on geochemical composition (Avendaño \& Cobo, 1998).

This lack in the information regarding Spanish reservoirs is especially unfortunate because lake and reservoir sediments are one of the most important archives of biogeochemical data. This information is very useful for reconstructions of ecological processes occurring across the whole watershed system. Changes in composition and structure along a vertical profile offer a time-series that covers an enhanced breadth of temporal variability, whilst even a thin layer of superficial sediment is the result of processes at an annual scale, so its chemical composition and grain-size structure reflect the system dynamics over a wider period than water column characteristics do.

The main inputs involved in the formation of reservoir sediments are similar to those involved in the formation of fine-grained facies in marine basins: 1) allochthonous detritus derived from weathering of catchments soils and parent rock, 2) biogenic components derived both from primary and secondary production and 3 ) authigenic material precipitated at or near the sediment-water interface as a consequence of $\mathrm{E}_{\mathrm{H}^{-}} \mathrm{pH}$ controlled organic and inorganic precipitation (Sageman \& Lyons, 2004). These biogeochemical processes may be reconstructed using (as proxy data) the elemental concentration/accumulation values. Proxies employed in the study of sedimentary material should be based on a known relationship between a biogeochemical process and the corresponding flux of the related specific components. However, elemental concentration data suffer from the inherent limitation of reciprocal dilution (i.e. the constant sum effect) that may lead to spurious correlations and ambiguous determination of fluxes (Rollinson, 1993, Sageman \& Lyons, 2004). To avoid this problem, the use of elemental ratios (Turekian \& Wedepohl, 1961; Calvert \& Pedersen, 1993, Lyons et al., 2003) serves to normalize components to major dilutants. This allows for a better identification of the contributions to the flux variability, although normalization techniques must be applied carefully (Van de Weijden, 2002). Moreover, correct interpretation of elemental ratios depends on distinguishing elemental sources and transport modes. For example, in some cases an increase in the $\mathrm{Ti} / \mathrm{Al}$ ratio has been related to increased eolian flux (Bertrand et al., 1996), but in other cases the same signal has been related to increased fluvial inputs (Murphy et al., 2000). Consequently, interpretation of elemental ratios may be different depending on limnological regions which are associated with different catchment mineralogy.

In order to give a preliminary approach to the geochemistry of sediments in Spanish reservoirs, the concentration of major elements and significant element ratios in two sets of data from different limnological regions are discussed in the next sections. The main purposes of this approach are to:

A) Provide a reference data-set on chemical composition of sediments in Spanish reservoirs.

B) Relate reservoirs sediment geochemistry with the limnological regions identified by previous studies.

C) Establish the main relationships between elemental ratios and ecological processes in reservoirs and their dependence on the geological nature of the watershed at the regional scale. 
Table 1.- Reservoirs and their hydrographical watershed included in the study. Los embalses y su cuenca hidrográfica que se han muestreado para este estudio

\begin{tabular}{ll}
\hline Reservoir & Hydrographical watershed \\
\hline Set a: Catalonian reservoirs & \\
Santa Ana & Noguera Ribagorzana \\
Canelles & Noguera Ribagorzana \\
Escales & Noguera Ribagorzana \\
Talarn & Noguera Pallaresa \\
Terradets & Noguera Pallaresa \\
Camarasa & Noguera Pallaresa \\
St Llorenç Mongai & Segre \\
Oliana & Segre \\
Sau & Ter \\
Susqueda & Ter \\
Baells & Llobregat \\
St Pons & Llobregat \\
Riba roja & Ebro \\
Flix & Ebro \\
Siurana & Ebro \\
Foix & Foix \\
Boadella & Muga \\
Santa Fe & Tordera \\
Riudecanyes & Riudecanyes \\
Set b: Lozoya reservoirs & \\
Pinilla & Lozoya \\
Rio Sequillo & Lozoya \\
Puentes Viejas & Lozoya \\
Atazar & Lozoya \\
\hline & Lozoya \\
\hline
\end{tabular}

\section{STUDY AREA}

In this study, two data sets on sediment composition have been analysed. The first corresponds to sediments of 19 Catalonian reservoirs, which belong to ten hydrographical watersheds (Table 1). From their characteristics, these reservoirs (except Boadella) may be included in the limnological region East of the Iberian Peninsula as defined by Margalef et al (1976). This region is characterized by sedimentary catchments areas and reservoirs present high values of conductivity, alkalinity and dissolved calcium (Margalef et al, 1976, Armengol et al., 1991). The second data set corresponds to sediments of five enchained reservoirs in the Lozoya river, a siliceous watershed (Table 1). These may be included in the limnological region West of the Iberian Peninsula. Reservoirs in this region are characterized by low conductivity, alka- linity and dissolved calcium concentrations (Margalef et al., 1976, Armengol et al., 1991).

\section{MATERIAL AND METHODS}

Data from Catalonian reservoirs were obtained on superficial samples $(0-5 \mathrm{~cm})$ collected at a deep point, usually close to the dam. For the Lozoya reservoirs, data were obtained on superficial samples $(0-2.5 \mathrm{~cm})$, collected at three sampling points for each reservoir: upper, middle and dam.

In all cases, sediment samples were immediately frozen and kept at $-20^{\circ} \mathrm{C}$ until processed. Then, samples were dried at $70^{\circ} \mathrm{C}$ and finely ground to perform the chemical analysis. Elemental composition was always analysed by X-ray fluorescence after fusion with lithium tetraborate. This method has several advantages: it is a non-destructive method that avoids loss of material and sample contamination during pretreatment (Somogyi et al., 1997), it avoids the use of hazardous chemicals (Tung, 2004), and it does not suffer from matrix effects (Lopez \& Morgui, 1991, Somogyi et al., 1997). The main disadvantage, however, is that XRF gives no information about the chemical form of the element. Even so, as will be described in the next sections, some of the mineral characteristics and chemical behaviour of the elements may be inferred from the analysis of the elemental ratios.

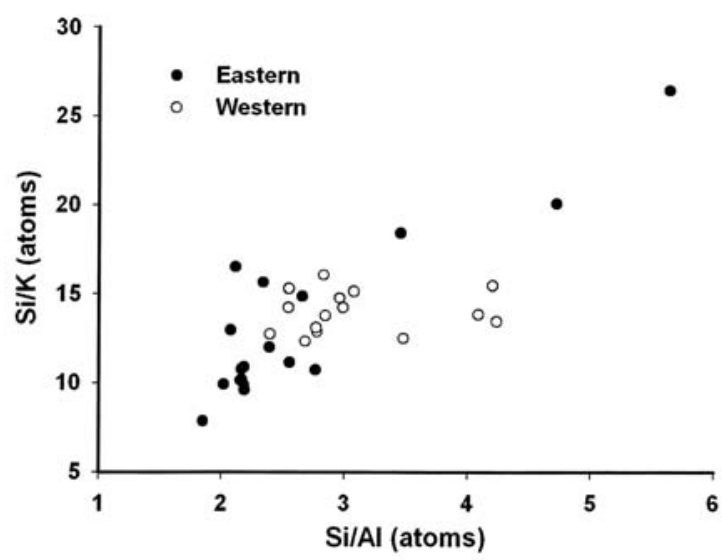

Figure 1.- Relationship between the sedimentary $\mathrm{Si} / \mathrm{Al}$ and $\mathrm{Si} / \mathrm{K}$ ratios expressed in atoms. Relaciones entre las relaciones atómicas Si/Al y Si y Si/k del sedimento. 


\section{RESULTS AND DISCUSION}

\section{Alumino-silicate Elements}

Silicon, aluminium and potassium are the main elements associated with the alumino-silicate fraction. These three elements are present in primary silicates as, for example, feldspars and in secondary minerals such as clays. Silicon is the most abundant element, reaching $310 \mathrm{mg}^{-1} \mathrm{~g}^{-1}$ (equivalent to 11.5 mg-at. $\mathrm{g}^{-1}$ ) in sediments of reservoirs from the Western region, but it is also abundant in reservoirs from non-siliceous catchments, where the mean value is $183 \mathrm{mg} . \mathrm{g}^{-1}$ (6.53 mg-at. $\left.\mathrm{g}^{-1}\right)$ (Table 2 ).

In general, silicon, aluminium and potassium are closely related, although several noticeable trends may be distinguished by analysing the behaviour of ratios between them in different conditions. The ratio $\mathrm{K} / \mathrm{Al}$ is nearly constant and does not show significant differences between regions, reservoirs or across the longitudi- nal axis in a reservoir (Table 3 ). The mean value for the Western area, 0.22, is similar to that reported for the continental crust (Condie, 1993), whereas the slightly lower mean observed in Eastern sediments, 0.20, approaches to that of carbonates (Gao et al., 1998).

The ratios $\mathrm{Si} / \mathrm{Al}$ and $\mathrm{Si} / \mathrm{K}$ present a wider range in the Eastern reservoirs than in the Western ones (Table 3). Moreover, in non-siliceous catchments, $\mathrm{Si} / \mathrm{Al}$ and $\mathrm{Si} / \mathrm{K}$ varied simultaneously, but in the siliceous watershed $\mathrm{Si} / \mathrm{K}$ remains fairly constant whereas $\mathrm{Si} / \mathrm{Al}$ show greater variation (Fig. 1). In the Lozoya reservoirs $\mathrm{Si} / \mathrm{Al}$ decreases along consecutive reservoirs, from 3.21 at Pinilla to 2.82 at El Atazar and also tends to decrease towards the dam within a single reservoir (Fig. 2A). A similar pattern may be observed in some Eastern reservoirs, e.g. those located in the Noguera Ribargozana watershed, where $\mathrm{Si} / \mathrm{Al}$ varies from 5.64 at Talarn to 2.08 at Camarasa (Fig. 2B).
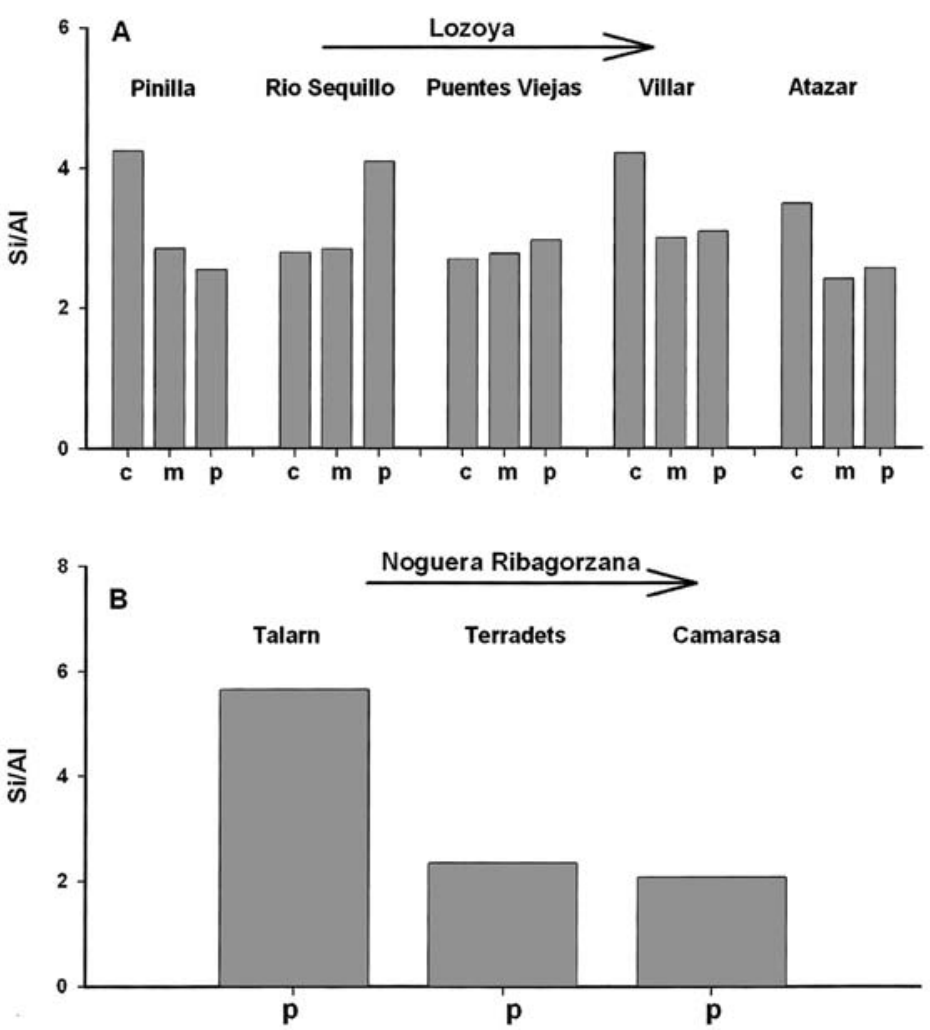

Figure 2.- Changes in the sedimentary $\mathrm{Si} / \mathrm{Al}$ ratio in reservoirs along the river flow. A: Lozoya river. B: Noguera Ribagorzana river. Ratios are expressed in atoms. Cambios en la relación Si/Al en el sedimento de los embalses según la dirección en el flujo de agua del río, A: río Lozoya. B: rio Noguera Ribagorzana. La relaciones se expresan en átomos. 
Studies on the mineralogy of Eastern reservoir sediments have shown clays, as illite and kaolinite, and quartz as the main silicate minerals (Navas et al., 2004). In this case, the ratios $\mathrm{Si} / \mathrm{Al}$ and $\mathrm{Si} / \mathrm{K}$ depends on the proportion of the coarse materials, mainly formed by quartz sands which contains only silicon, and fine clays which contain silicon, aluminium and potassium. When other processes are unlikely to have been comparatively significant, $\mathrm{Si} / \mathrm{Al}$ and $\mathrm{Si} / \mathrm{K}$ should vary simultaneously as observed in the studied reservoirs. Increase in $\mathrm{Si} / \mathrm{Al}$ and $\mathrm{Si} / \mathrm{K}$ may be related to enhanced input of quartz, which in turn may be due to eolian inputs (Werne et al., 2002), but also to higher energy transport. In agreement with this, the higher values of $\mathrm{Si} / \mathrm{Al}$ and $\mathrm{Si} / \mathrm{K}$ observed in reservoirs from the upper catchments areas may be explained as consequence of the higher energy transport. As a whole, the results suggest that in the Eastern area, both ratios may be used as indicators of hydrodynamic and transport processes.

In the Western area, silicate minerals are present as aluminosilicates with different degrees of meteorization, from feldspars minerals to meteorized clays. Chemical weathering of silicates usually comes through incongruent dissolution, i.e. a new solid phase is formed from the solid background material. Globally this process involves a release of silicate and potassium to the water, whereas aluminium remains in the solid phase (Tardy et al., 2004). As a consequence, meteorization of silicate rocks determines the change in the $\mathrm{Si} / \mathrm{Al}$ ratio in the solid phase, which decreases as the process continues, whereas $\mathrm{Si} / \mathrm{K}$ is not modified. The pattern of variation observed in the Lozoya reservoirs (Fig. 2A) agrees with this behaviour. The lower values of $\mathrm{Si} / \mathrm{Al}$ observed near the dams, and in the lower reservoirs (at watershed scale) indicates that the most meteorized materials with lower $\mathrm{Si} / \mathrm{Al}$ ratio are accumulated down the river flow. So, in the Western region $\mathrm{Si} / \mathrm{Al}$ ratios appear related to chemical weathering rather than to hydrodynamics.

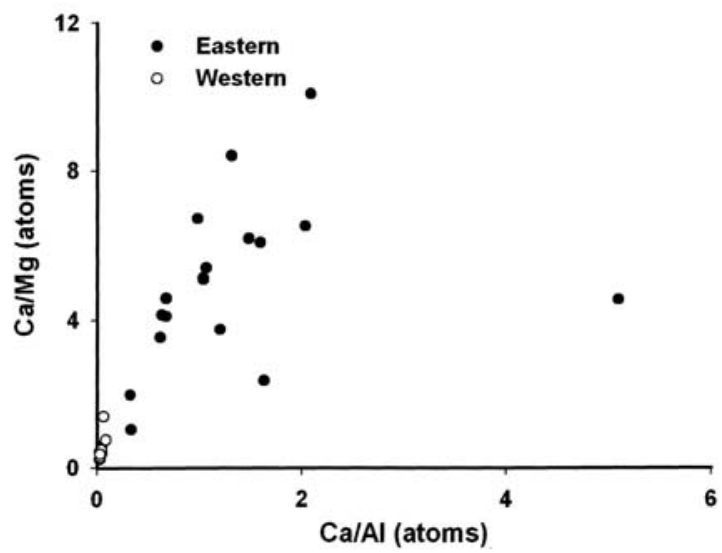

Figure 3.- Relationship between the sedimentary $\mathrm{Ca} / \mathrm{Al}$ and $\mathrm{Ca} / \mathrm{Mg}$ ratios expressed in atoms. Relaciones entre las relaciones atómicas $\mathrm{Ca} / \mathrm{Al} \mathrm{y} \mathrm{Ca} / \mathrm{Mg}$ del sedimento.

Table 2.- Range, mean, standard deviation and coefficient of variation for element concentrations in reservoir sediments grouped by limnological region. Rango, media, desviación estandard y coeficiente variación en los sedimentos de los embalses estudiados agrupados por regiones limnológicas.

\begin{tabular}{|c|c|c|c|c|c|c|c|c|c|}
\hline & $\underset{\text { mg-at/g }}{\text { Al }}$ & $\begin{array}{c}\text { K } \\
\text { mg-at/g }\end{array}$ & $\begin{array}{c}\mathrm{Ca} \\
\mathrm{mg}-\mathrm{at} / \mathrm{g}\end{array}$ & $\begin{array}{c}\text { Mg } \\
\text { mg-at/g }\end{array}$ & $\underset{\text { mg-at/g }}{\text { Si }}$ & $\begin{array}{c}\text { Fe } \\
\text { mg-at/g }\end{array}$ & $\underset{\mu g-a t / g}{M n}$ & $\underset{\mu \mathrm{Ti}}{\mu-a t / g}$ & $\begin{array}{c}\text { P } \\
\mu \mathrm{g}-\mathrm{at} / \mathrm{g}\end{array}$ \\
\hline \multicolumn{10}{|c|}{ Eastern Region } \\
\hline Max & 3.83 & 0.90 & 5.53 & 1.40 & 9.41 & 0.87 & 27.03 & 108.75 & 65.47 \\
\hline Min & 1.08 & 0.20 & 0.19 & 0.26 & 3.75 & 0.25 & 3.45 & 35.00 & 8.45 \\
\hline Med & 2.67 & 0.54 & 2.71 & 0.64 & 6.53 & 0.60 & 10.06 & 67.19 & 27.61 \\
\hline Sd & 0.76 & 0.16 & 1.24 & 0.31 & 1.19 & 0.17 & 5.63 & 16.83 & 16.17 \\
\hline $\mathrm{CV}$ & 28.51 & 29.78 & 45.88 & 48.88 & 18.29 & 28.53 & 56.00 & 25.05 & 58.55 \\
\hline \multicolumn{10}{|c|}{ Western Region } \\
\hline Max & 3.71 & 0.86 & 0.21 & 0.44 & 11.52 & 0.98 & 73.89 & 101.25 & 79.55 \\
\hline Min & 2.45 & 0.57 & 0.07 & 0.17 & 8.37 & 0.38 & 4.60 & 40.31 & 25.70 \\
\hline Med & 3.14 & 0.69 & 0.12 & 0.34 & 9.54 & 0.73 & 16.69 & 81.67 & 49.80 \\
\hline Sd & 0.33 & 0.08 & 0.04 & 0.07 & 0.93 & 0.19 & 17.55 & 16.20 & 16.05 \\
\hline $\mathbf{C V}$ & 10.62 & 12.05 & 30.87 & 19.42 & 9.78 & 26.41 & 105.11 & 19.84 & 32.24 \\
\hline
\end{tabular}




\section{Alcaline-Earth Elements}

Calcium and magnesium are the most abundant alkaline-earth elements in reservoir sediments. Calcium is mainly present as carbonate minerals, its concentration being more than twenty times higher in the Eastern reservoirs than found in the Western ones (Table 2).

In the Eastern region, sedimentary calcium may attain $220 \mathrm{mg} \cdot \mathrm{g}^{-1}$, which represents that more than $50 \%$ of the dry weigh is found as carbonate mineral. Usually, calcium dominates over magnesium, the mean $\mathrm{Ca} / \mathrm{Mg}$ ratio (around 4.7) being higher that the value for carbonate rocks (Gao et al., 1998) and for sediments (Wedephol, 1995). $\mathrm{Ca} / \mathrm{Mg}$ ratio present in this region a wide range of variability with a coefficient of variation over $50 \%$ (Table 3 ). $\mathrm{Ca} / \mathrm{Mg}$ increased with $\mathrm{Ca} / \mathrm{Al}$ (Fig. 3) suggesting that even in sedimentary catchments, magnesium is mainly associated with the aluminosilicate fraction.

The relative abundance of sedimentary calcium, expressed by the $\mathrm{Ca} / \mathrm{Al}$ ratio is clearly related to water mineralization, as could be expected from the high solubility of calcite (Tardy et al., 2004). However, there is not a single relationship between these two variables, because the abundance of other soluble minerals, for example gypsum or halite, also

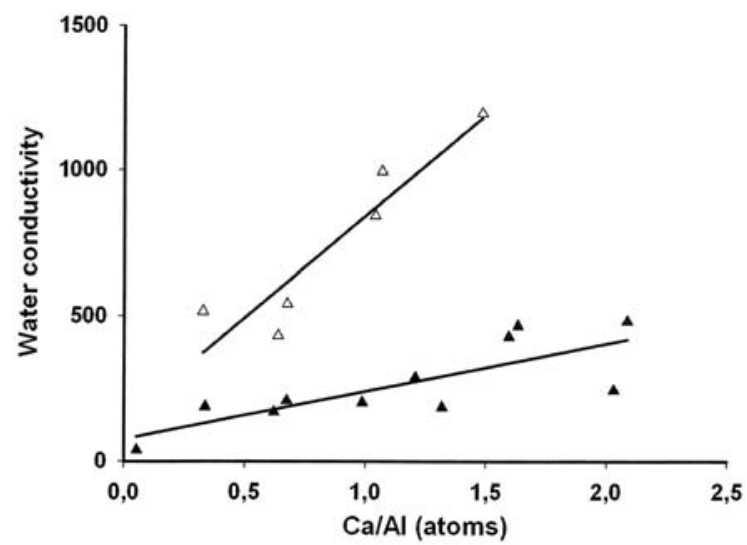

Figure 4.- Relationship between the sedimentary $\mathrm{Ca} / \mathrm{Al}$ ratio and water conductivity. Values of $\mathrm{Ca} / \mathrm{Al}$ are in atoms; values of conductivity are in $\mu \mathrm{S} \mathrm{cm} \mathrm{cm}^{-1}$. Relaciones entre el cociente $\mathrm{Ca} / \mathrm{Al}$ del sedimento y la conductividad del agua. El cociente Ca/Al esta expresado como relación atómica y la conductivi-

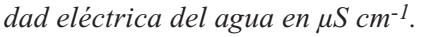

determine the conductivity associated with a specific $\mathrm{Ca} / \mathrm{Al}$ value. Differences in mineralogy of the catchments are reflected in the different slopes of the regression lines between water conductivity and the $\mathrm{Ca} / \mathrm{Al}$ ratio in sediments and are expressed in the following two equations (see also Fig. 4):

Cond $=164 * \mathrm{Ca} / \mathrm{Al}+74.9 ; \mathrm{r}^{2}=0.63 ; \mathrm{N}=11$

for reservoirs in the Noguera Ribagorzana, Noguera Pallaresa, Segre, Llobregat, Tordera and Siurana catchments and,

Cond $=697 * \mathrm{Ca} / \mathrm{Al}+144 ; \mathrm{r}^{2}=0.87 ; \mathrm{N}=6$

for Ter, Ebre and Foix catchments.

In the Western region, calcium is a minor component of sediments with a mean concentration below $0.5 \mathrm{mg} . \mathrm{g}^{-1}$. In siliceous catchments a significant amount of the dissolved calcium comes from weathering of Ca-aluminosilicates through anorthite hydrolysis according to the equation (3) (Tardy et al., 2004),

$$
\begin{gathered}
\mathrm{CaAl}_{2} \mathrm{Si}_{2} \mathrm{O}_{8(\mathrm{~s})}+2 \mathrm{CO}_{2}+3 \mathrm{H}_{2} \mathrm{O}= \\
=1 / 4 \mathrm{Al}_{2} \mathrm{Si}_{2} \mathrm{O}_{5}(\mathrm{OH})_{4(\mathrm{~s})}+\mathrm{Ca}^{2+}+2 \mathrm{HCO}_{3}^{-}
\end{gathered}
$$

The stoichiometry of compounds released to water through the reaction (3) is the same as from calcite dissolution, but the concentration is considerably lower because silicates are poorly soluble, which explains the lower conductivity and dissolved calcium concentrations in the Western reservoirs.

Dissolution of anorthite involves a diminution of the $\mathrm{Ca} / \mathrm{Al}$ ratio in the solid phase, as wells as dissolution of calcite. In the Lozoya reservoirs, $\mathrm{Ca} / \mathrm{Al}$ diminishes from an average value of 0.06 in Pinilla to 0.04 in El Atazar, an also decreases towards the dam inside each reservoir (Fig. 5). This pattern of variation could be related to calcite or silicate weathering. However, the value of $\mathrm{Ca} / \mathrm{Al}$ in the end of Pinilla, $\mathrm{Ca} / \mathrm{Al}=0.09$, is slightly lower than the observed in granites (Wedepohl, 1995), what suggests that weathering of $\mathrm{Ca}$-silicates is the main process determining $\mathrm{Ca} / \mathrm{Al}$ ratio in this watershed. 
Table 3.- Range, mean, standard deviation and coefficient of variation for selected atomic ratios between elements in reservoir sediments grouped by limnological region. Rango, media, desviación estandard y coeficiente de variación para los cocientes atómicos del sedimento de los embalses que se han utilizado en el estudio, agrupados por regiones limnológicas.

\begin{tabular}{|c|c|c|c|c|c|c|c|c|c|c|c|}
\hline & $\mathbf{K} / \mathbf{A l}$ & $\mathrm{Si} / \mathbf{K}$ & $\mathbf{S i} / \mathbf{A l}$ & $\mathrm{Ca} / \mathrm{Al}$ & $\mathrm{Ca} / \mathrm{Mg}$ & $\mathrm{Fe} / \mathrm{Al}$ & $\begin{array}{c}\mathrm{Mn} / \mathrm{Fe} \\
* 1000\end{array}$ & $\begin{array}{c}\text { P/Ca } \\
* 1000\end{array}$ & $\begin{array}{c}\mathrm{P} / \mathrm{Fe} \\
* 1000\end{array}$ & $\begin{array}{c}\text { P/Al } \\
* 1000\end{array}$ & $\begin{array}{c}\text { Mn/Al } \\
* 1000\end{array}$ \\
\hline \multicolumn{12}{|c|}{ Eastern Region } \\
\hline Max & 0.26 & 26.41 & 5.64 & 5.09 & 10.07 & 0.26 & 31.15 & 197.75 & 87.30 & 22.49 & 7.11 \\
\hline Min & 0.13 & 7.84 & 1.85 & 0.05 & 0.60 & 0.20 & 10.23 & 1.53 & 22.96 & 4.83 & 2.21 \\
\hline Mean & 0.20 & 13.20 & 2.65 & 1.27 & 4.72 & 0.23 & 16.25 & 22.52 & 44.31 & 10.19 & 3.72 \\
\hline Sd & 0.03 & 4.69 & 1.00 & 1.11 & 2.43 & 0.02 & 5.52 & 44.86 & 18.12 & 4.76 & 1.41 \\
\hline $\mathrm{CV}$ & 16.11 & 35.54 & 37.88 & 87.75 & 51.47 & 6.82 & 33.97 & 199.20 & 40.90 & 46.66 & 38.05 \\
\hline \multicolumn{12}{|c|}{ Western Region } \\
\hline Max & 0.32 & 16.04 & 4.24 & 0.09 & 0.76 & 0.31 & 75.49 & 935.96 & 97.42 & 26.53 & 21.19 \\
\hline Min & 0.17 & 12.32 & 2.40 & 0.03 & 0.23 & 0.15 & 11.68 & 137.85 & 42.72 & 8.34 & 1.87 \\
\hline Mean & 0.22 & 13.96 & 3.09 & 0.04 & 0.37 & 0.23 & 20.83 & 465.75 & 69.13 & 15.87 & 5.09 \\
\hline $\mathrm{Sd}$ & 0.05 & 1.17 & 0.62 & 0.02 & 0.14 & 0.05 & 16.48 & 247.80 & 16.39 & 5.09 & 4.89 \\
\hline $\mathrm{CV}$ & 20.58 & 8.36 & 19.91 & 39.52 & 36.76 & 21.77 & 79.11 & 53.21 & 23.71 & 32.06 & 95.98 \\
\hline
\end{tabular}

\section{Metal Elements}

Iron is, with aluminium, the main metallic element present in reservoir sediments. Iron geochemistry is, in some aspects, similar to that of aluminium. Both elements are present in primary rocks as alumino-silicates and they may form oxi-hidroxides after chemical weathering. Moreover, both present low concentrations in carbonate rocks (Gao et al., 1998). Globally, these trends are reflected, in the lower iron concentrations observed in the Eastern reservoirs (Table 2), and in the constancy of the $\mathrm{Fe} / \mathrm{Al}$ ratio that presents the same average value $(0.23)$ in both areas (Table 3 ).
Nevertheless, there are significant differences in iron and aluminium biogeochemistry, one of the most important being a higher iron loss rate from primary silicates. In siliceous watersheds, river and lixiviation water may carry significant amounts of dissolved iron as a result of chemical weathering of soils. In fact, reservoirs in the Western region usually present high concentrations of dissolved iron (Margalef et al., 1976). At $\mathrm{pH}$ values observed in reservoirs, usually up to 6, part of this dissolved iron may precipitate (Stumm \& Morgan, 1981), increasing moderately the $\mathrm{Fe} / \mathrm{Al}$ ratio in sediments. The presence of authigenic iron oxides explains the variation of $\mathrm{Fe} / \mathrm{Al}$ ratio in the

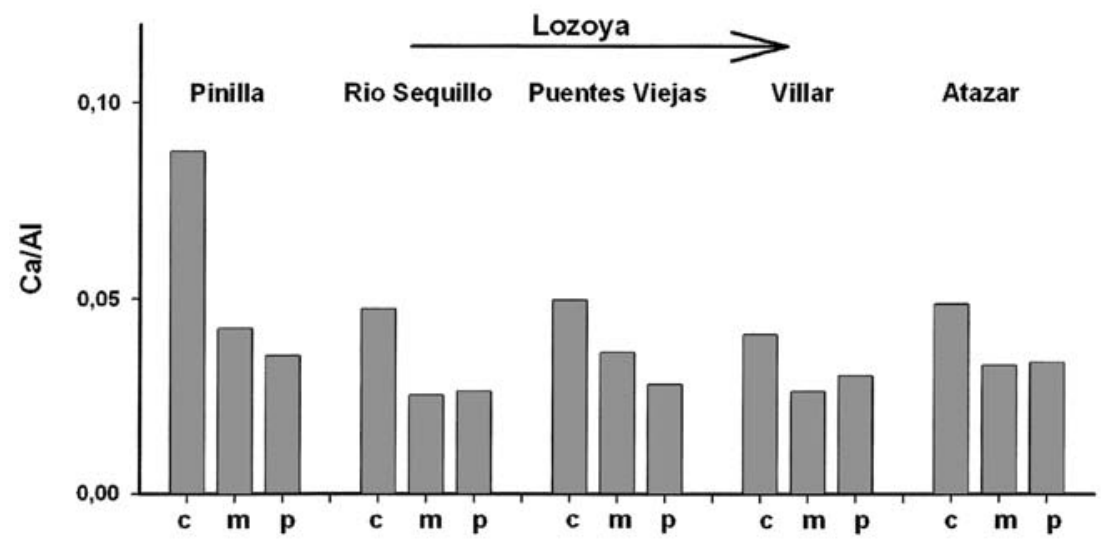

Figure 5.- Changes in the sedimentary $\mathrm{Ca} / \mathrm{Al}$ ratio in reservoirs located along the Lozoya river. Values are in atoms. Cambios en el cociente Ca/Al en el sedimento de los embalses situados a lo largo del río Lozoya. Valores expresados como relación atómica. 


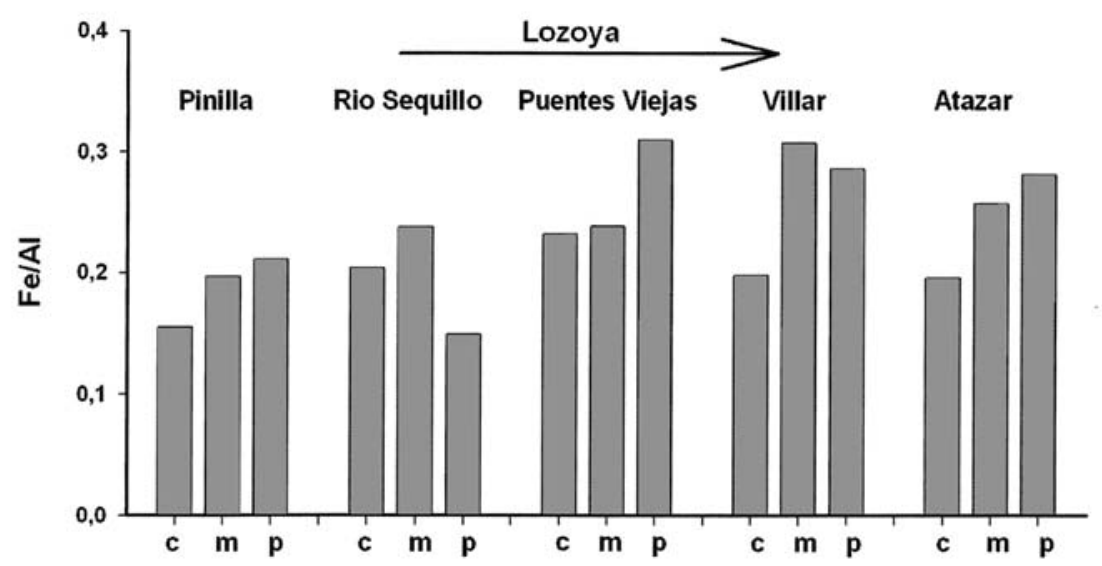

Figure 6.- Changes in the sedimentary Fe/Al ratio in reservoirs located along the Lozoya river. Values are in atoms. Cambios en el conciente $\mathrm{Fe} / \mathrm{Al}$ del sedimento de los embalses situados a lo largo del río Lozoya. Valores expresados como relación atómica.

Lozoya reservoirs, where it increases from near 0.20 in Pinilla and Rio Sequillo to around 0.25 in Puentes Viejas, Villar and El Atazar (Fig. 6). Indeed, this variation causes the higher coefficient of variation observed for $\mathrm{Fe} / \mathrm{Al}$ ratio in the Western region (Table 3).

The second important difference between iron and aluminium geochemistry is their different behaviour under reducing conditions. Iron's solubility increases with decrease of $\mathrm{E}_{\mathrm{H}}$ (Stumm \& Morgan, 1981), which determines the wellknown negative correlation between dissolved iron and dissolved oxygen (Margalef et al., 1976). Because aluminium oxides does not dissolve at the usual $\mathrm{pH}$ and redox conditions observed in reservoirs (Drever, 1982), a significant correlation between dissolved oxygen and $\mathrm{Fe} / \mathrm{Al}$ ratio in sediment could be expected. However, at least in the Eastern reservoirs, for which data on dissolved components are available, this correlation is not observed (Fig. 7). In the Eastern reservoirs, sulphate is usually present at concentrations of up to $1 \mathrm{mM}$. (Margalef et al., 1976), so sulphate-reduction is not limited by substrate availability. In this case, iron dissolved from oxi-hidroxide phases re-precipitates as iron sulphides preventing the loss of iron from the solid phase. In vertical profiles, the increase in the Fe/Al ratio associated with iron sulphide deposition clearly distinguishes the transition from oxic to anoxic zones or events (Van Capellen et al., 1998). At a regional level, however, $\mathrm{Fe} / \mathrm{Al}$ ratio is not a useful indicator, as redox conditions may change iron distribution in the sediment, but without a significant modification of its total concentration. This may explain the low variability in the $\mathrm{Fe} / \mathrm{Al}$ ratio in Eastern reservoirs in spite of their different redox characteristics.

Manganese, that can be present in sediment as carbonate phases and oxi-hidroxide phases, is usually a minor component of the sediments in reservoirs, with values below $0.5 \%$ of dry weight. The mean value for the Western reservoirs, 16.7 $\mu \mathrm{g}$-at. $\mathrm{g}^{-1}$, is higher than for the Eastern ones (Table 2), but this value may be an overestimation determined by the high level of manganese observed in El Atazar sediments, where it reaches up to $70 \mu \mathrm{g}$-at.g ${ }^{-1}$ in the dam. If samples from El Atazar are excluded from the data set, the mean value for Western reservoirs become $10.6 \mu \mathrm{g}$-at.g $\mathrm{g}^{-1}$ ( $\mathrm{sd}=$ $4.26 ; \mathrm{CV}=40.18$ ) which is very close to the observed in the Eastern reservoirs.

Manganese concentration depends on redox conditions in a similar way to iron. Below $\mathrm{E}_{\mathrm{H}}$ values around $500 \mathrm{mV}$ manganese occurs as the soluble ion in water, whereas $\mathrm{E}_{\mathrm{H}}$ values up to $500 \mathrm{mV}$ favour insoluble manganese oxides (Hem, 1981). This explains the significant correlation between dissolved manganese and oxygen depletion in water (Margalef et al., 1976). Consequently, $\mathrm{Mn} / \mathrm{Fe}$ and $\mathrm{Mn} / \mathrm{Al}$ ratios should be lower in sediment from reservoirs with bottom oxygen depletion and higher in 


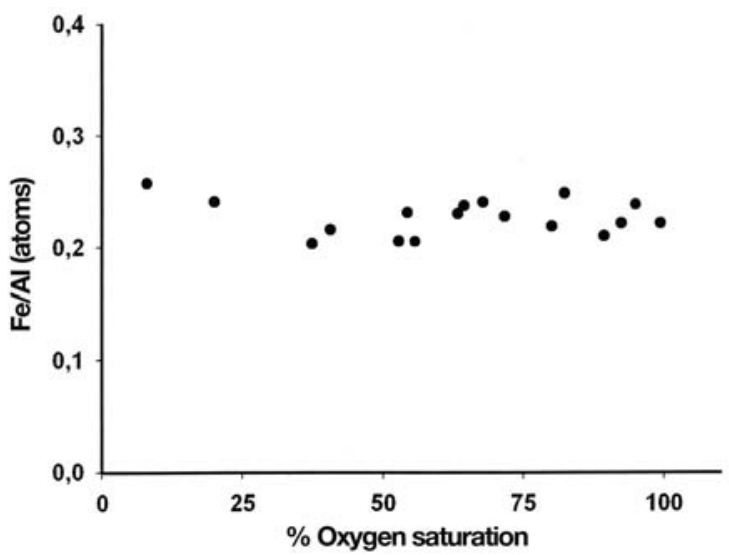

Figure 7.- Relationship between the sedimentary Fe/Al ratio and the annual average saturation of oxygen in bottom water. Values of $\mathrm{Fe} / \mathrm{Al}$ are in atoms. Relaciones entre el cociente $\mathrm{Fe} / \mathrm{Al}$ del sedimento y el promedio annual de saturación de oxígeno en el agua del fondo de los embalses. Los cocientes se expresan como relaciones atómicas.

sediments from reservoirs with well oxygenated hypolimnion. Some results at the Lozoya reservoirs are partially in agreement with this behaviour. El Atazar, with the highest $\mathrm{Mn} / \mathrm{Al}$ ratio $(>20$ in atomMn/1000 atomAl), is an oligotrophic reservoir without summer oxygen depletion (Armengol, com. per.). The upper reservoirs, mainly Puentes Viejas and Villar are more eutrophic and suffer from hipolimnetic anoxia in some periods (Armengol, com. per.) and correspondingly they present lower values of the $\mathrm{Mn} / \mathrm{Al}$ ratio $(<6$ atom $\mathrm{Mn} / 1000$ atomAl). The results observed suggest that manganese is released to the water in the upper reservoirs and then transported to the lower reservoirs where it precipitates due to the higher redox conditions.

In the Eastern reservoirs, no significant correlation is observed between bottom oxygen saturation and the $\mathrm{Mn} / \mathrm{Al}$ ratio. In fact one of the highest values of the $\mathrm{Mn} / \mathrm{Al}$ ratio (7.11 atomMn/ 1000 atomAl) appears at Susqueda with an average oxygen saturation in the bottom below $8 \%$. This suggests that concentrations and ratios of sedimentary manganese are also very sensitive to other factors (e.g. mineralogy of the catchments, carbonate equilibrium ...) in addition to the redox conditions. Consequently no generalizations of the significance of sedimentary manganese may be made at a global scale.

\section{Phosphorus}

Phosphorus is one of the elements that has been more studied in sediments of different bodies of water. Comparisons among data have to be done carefully because of the use of different methodologies, the results being, in many cases, affected by analytical procedures and by composition of the mineral matrix. Considering only the results for total phosphorus in superficial sediments, previous studies showed significant differences among Western and Eastern reservoirs, the first ones presenting higher concentrations of total phosphorus in sediments (Lopez \& Morgui, 1993).

The results observed here confirm previous observation: the mean value in the Western reservoirs is approximately twice the observed in the Eastern reservoirs, the coefficient of variation being similar in both areas (Table 2).

Sedimentary phosphorus is present in several solid phases: phosphorus associated with calcium carbonates (detrital carbonate-fluorapatite, hidroxiapatite and phosphorus adsorbed onto calcium carbonate), phosphorus bound onto metal oxides (both iron or aluminium oxi-hidroxides) and refractory organic phosphorus are usually the most abundant forms (e.g. Jensen et al., 1992; Baldwin, 1996; Lopez, 2004). The predominance of calcium bound phosphate in water bodies located in calcareous watersheds is a common feature and has been confirmed by several studies (Armengol et al., 1984, 1986; Lopez \& Morgui, 1993). In addition, precipitation of calcium carbonate phosphate phases has been proposed as the main chemical mechanism controlling dissolved phosphate in these areas and preventing hard-water bodies from eutrophication (Estrada, 1978). By contrast, in siliceous watersheds iron-bound phosphate and/or organic phosphates are the main sedimentary forms (Lopez \& Morgui, 1993). Because ironbound phosphate is formed through an adsorptive process and it is released to the water column under anaerobic conditions, water bodies located in siliceous catchments are expected to present higher dissolved phosphate, mainly if anoxic episodes occur. Actually, although a high 
variability existed, Western reservoirs presented higher values of dissolved phosphate that Eastern reservoirs (Margalef et al., 1976).

Taking into account that elements associated in the same mineral phase present a constant ratio (Rollinson 1993), when sedimentary phosphorus is mainly associated to calcium phases $\mathrm{P} / \mathrm{Ca}$ should be fairly constant, whereas if sedimentary phosphorus is mainly seen as ironbound phases the constant ratio should be $\mathrm{P} / \mathrm{Fe}$. Finally, variable $\mathrm{P} / \mathrm{Ca}$ and $\mathrm{P} / \mathrm{Fe}$ indicates an accumulation of organic phosphorus as the main mechanism controlling the amount of total phosphorus in sediments. So, from the previous considerations, we could expect a lower variability of the $\mathrm{P} / \mathrm{Ca}$ ratio in Eastern reservoirs and a lower variability of the $\mathrm{P} / \mathrm{Fe}$ ratio in Western ones. The values observed agree with those expected for the Western reservoirs. The coefficient of variation for $\mathrm{P} / \mathrm{Fe}$ in this area is below $25 \%$, with an average value close to 70 atom $\mathrm{P} /$ 1000 atom Fe (Table 3). However, in Eastern reservoirs the results do not match predicted ones. In this area, $\mathrm{P} / \mathrm{Ca}$ present a coefficient of variation near $200 \%$, much greater than that of $\mathrm{P} / \mathrm{Fe}$ or $\mathrm{P} / \mathrm{Al}$ (around $50 \%$ ) (Table 3 ).

The clearest relationship between sedimentary phosphorus and other sedimentary elements appears between iron and phosphorus when concentrations are normalized relative to the alumi-

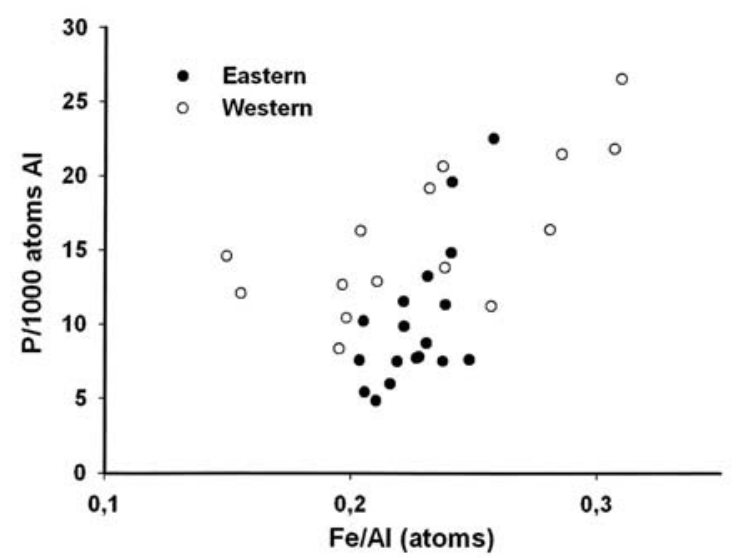

Figure 8.- Relationship between the sedimentary $\mathrm{Fe} / \mathrm{Al}$ and $\mathrm{P} / \mathrm{Al}$ ratios. $\mathrm{Fe} / \mathrm{Al}$ are in atoms. $\mathrm{P} / \mathrm{Al}$ are in atoms $\mathrm{P} / 1000$ atoms Al. Relaciones entre los cocientes Fe/Al y P/Al del sedimento. El cociente Fe/Al esta expresado como una relación atómica y el P/Al esta en átomos de P / 1000 átomos de Al. nium content (i.e. when $\mathrm{P} / \mathrm{Al}$ and $\mathrm{Fe} / \mathrm{Al}$ ratios are used instead of rough concentrations) (Fig. 8). The regression equations between these variables are significant for both areas, with a higher slope for the Eastern area (equation 4) than for the Western one (equation 5),

$\mathrm{P} / \mathrm{Al}=\mathrm{Fe} / \mathrm{Al} * 203.31-35.89 ; \mathrm{r}^{2}=0.44$

$\mathrm{P} / \mathrm{Al}=\mathrm{Fe} / \mathrm{Al} * 78.37-2.30 ; \mathrm{r}^{2}=0.64$

where $\mathrm{P} / \mathrm{Al}$ expressed in atomsP/1000 atoms $\mathrm{Al}$, and $\mathrm{Fe} / \mathrm{Al}$ expressed in atom $\mathrm{Fe} /$ atom $\mathrm{Al}$.

This relationship does not reflect dominance of any particular sedimentary phosphorus fraction. What it really reflects is that the increase of phosphate concentration over the background composition (which in turns may be dominated by calcium, iron or organic phosphorus) is linked with the increase in iron across the same background material. It is well known that authigenic iron oxi-hidroxides have a high capacity to adsorb phosphorus onto their surface (Likjlema, 1980; Lopez et al., 1996). Thus, precipitation and accumulation of authigenic iron-oxides causes a corresponding increase in $\mathrm{P} / \mathrm{Al}$ and $\mathrm{Fe} / \mathrm{Al}$ and seem to be the main process explaining the global variability observed in Spanish reservoirs. Nevertheless, the high variability in the $\mathrm{P} / \mathrm{Fe}$ ratio observed in the Eastern reservoirs also indicate that other processes have to be taken into account in order to explain the variability of sedimentary phosphorus within calcareous areas.

\section{INFLUENCE OF THE REGIONAL LIMNOLOGY ON THE ELEMENTAL RATIOS}

The determination of the elemental composition of sediments is relatively easy to do, being low- time consuming in terms of sampling and analytical procedures. For this reason, it may be widely used in monitoring and management studies of reservoirs. The variation in sediment composition detailed in previous sections indicate that interpretation of elemental ratios as 
indicators of ecological processes in reservoirs have to always be done in the context of the limnological region where reservoir is located. Certainly, much more data on chemical composition of sediment in Spanish reservoirs is needed to draw a more precise relationship between biogeochemical processes and element ratios. Even so, from the initial data available, some indications regarding the ecological significance of elemental ratios are given here as a resume of previous comments.

$\mathrm{Si} / \mathrm{Al}, \mathrm{P} / \mathrm{Al}, \mathrm{P} / \mathrm{Fe}, \mathrm{Ca} / \mathrm{Al}$ and $\mathrm{Ca} / \mathrm{Mg}$ present significantly different values in the two main limnological regions of the Iberian Peninsula. The first three ratios have higher average value in the siliceous region of West Spain, whereas the two last ratios are higher in the calcareous area of East Spain. In addition to the different values observed in the two regions, the ecological significance of the elemental ratios also depends on the area.

In East Spain, characterized by catchments with sedimentary mineralogy, Si/Al and $\mathrm{Si} / \mathrm{K}$ ratios are closely related to energy transport, when both vary simultaneously. High values of these ratios are indicators of deposition of coarse particles, which in turns may be related to an increased eolian transport in deforested watersheds or with enhanced transport of eroding material. $\mathrm{Ca} / \mathrm{Al}$ ratio is mainly related with water mineralization, higher values of conductivity being associated with higher $\mathrm{Ca} / \mathrm{Al}$ and $\mathrm{Ca} / \mathrm{Mg}$ ratios. In the Eastern area, the slope of the regression line between $\mathrm{Ca} / \mathrm{Al}$ and conductivity reflects the presence of soluble minerals others than calcite, and, in some particular places, may be associated with contaminated inputs with a high concentration of dissolved salts. At a global scale, the presence of sedimentary minerals, which both have a high calcium content and are relatively soluble, causes some of the main characteristics of the reservoirs from the Eastern region: high concentrations of alkalinity and dissolved calcium and high $\mathrm{Ca} / \mathrm{Al}$ ratios in the sediments.

In West Spain, characterized by catchments with poorly soluble silicate minerals, the ratios $\mathrm{Si} / \mathrm{Al}$ and $\mathrm{Ca} / \mathrm{Al}$, are mainly related to chemical weathering. Both ratios decreased in the most meteorized materials, which, due to its lower grain-size, tend to be easily transported and accumulated downriver. The low solubility of silicates determines the low conductivity, alkalinity and dissolved calcium of these reservoirs.

Other ratios as $\mathrm{Si} / \mathrm{K}, \mathrm{K} / \mathrm{Al}$ and $\mathrm{Fe} / \mathrm{Al}$ show no differences between limnological regions.

Even so, the ratio Fe/Al seems to be very useful to approach the eutrophication process at a global scale. In both areas, East and West Spain, $\mathrm{Fe} / \mathrm{Al}$ is linked to the authigenic precipitation of iron oxides and it appears clearly related to the $\mathrm{P} / \mathrm{Al}$ content in sediments. Because iron precipitation is one of the most efficient processes removing dissolved phosphate from water, considering together $\mathrm{Fe} / \mathrm{Al}$ and $\mathrm{P} / \mathrm{Al}$ in sediments may give a good estimation of the capacity of sediments to act as a phosphorus sink.

\section{ACKNOWLEDGEMENTS}

We are grateful to $\mathrm{M}^{\mathrm{a}}$ Ángels Gallegos, Meritxell Granell, Isabel Reyes and Claudia Feijoo for their useful assistance on the field work and laboratory analysis. We also thank E. Seguí for XRF-analysis, and R. Rycroft for improving the English manuscript. Founding support for this research was provided by the Spanish Ministry of Education and Science (Projects REN2001-2185-CO2-O2/HID and CGL2004-05503-CO2-O1). The study of sediments also benefited by the contracts 303194 and 302081 of the Bosch i Gimpera Fundation with the Water Suppy Company Canal de Isabel II and the Catalan Water Agency.

\section{REFERENCES}

ARMENGOL, J., J. L. RIERA, \& J. A. MORGUI. 1991. Major ionic composition in the Spanish reservoirs. Verh. int. Ver. Limnol., 24: 1363-1366.

ARMENGOL, J., M. CRESPO, \& J. A. MORGUI. 1984. Phosphorus compounds in the sediment of the Sau reservoir (Barcelona, N.E. Sapin) throughout its twenty-years existence. Verh. int. Ver. Limnol., 22: 1536-1540.

ARMENGOL, J., M. CRESPO, J. A. MORGUI, \& A. VIDAL. 1986. Phosphorus budgets and forms of 
phosphorus in the Sau reservoir sediment - an interpretation of the limnological record. Hydrobiologia, 143: 331-336.

AVENDAÑO, C. \& R. COBO. 1998. Seguimiento de los sólidos en suspensión durante el vaciado del embalse de Joaquin Costa. Limnetica, 14: 113-120.

BALDWIN, D. S. 1996. The phosphorus composition of a diverse series of Australian sediments. Hydrobiologia, 335: 63-73.

BERTRAND, P., G. B. SHIMMIELD, P. MARTINEZ, F. R. GROUSSET, F. JORISSEN, M. PATERNE, C. PUJOL, I. BOULOUBASSI, P. BUAT-MENARD, J. P. PEYPOUQUET, L. BEAUFORT, M. A. SICRE, E. LALLIER-VERGES, J. M. FOSTER, \& Y. TERNOIS. 1996. The glacial ocean productivity hypothesis: the importance of regional temporal and spatial studies. Mar. Geol., 130: 1-9.

BOAVIDA, M. J. \& R. T. MARQUÉS. 1996.Total phosphorus as an indicator of trophic state of portuguese reservoirs. Limnetica, 12: 31-38.

CALVERT, S. E. \& T. F. PEDERSEN. 1993. Geochemistry of recent oxic and anoxic marine sediments: implications for the geological record. Mar. Geol., 113: 67-88.

CONDIE, K. C. 1993. Chemical composition and evolution of the upper continental crust: contrasting results from surface samples and shales. Chem. Geol., 104: 1-37

DASI, M. J., M. R. MIRACLE, A. CAMACHO, J. M. SORIA, \& E. VICENTE. 1998. Summer phytoplankton assemblages across trophic gradients in hard-water reservoirs. Hydrobiologia, 370: 27-43.

DE VENTE, J., J. POESEN, \& G. VERSTRAETEN. 2005. The application of semi-quantitative methods and reservoir sedimentation rates for the prediction of basin sediment yield in Spain. $J$. Hydrology, 305: 63-86.

DIAZ, M., F. CABEZAS, \& F. L. BERMUDEZ. 1992. Erosion and fluvial sedimentation in the river Segura basin (Spain). Catena, 19: 379-392.

DREVER, J. I. 1982. The geochemistry of natural waters. Englewood Cliffs, N. J. Prentice Hall. 388 pp.

ESTRADA, M. 1978. Relationship among biological and physicochemical parameters in Spanish reservoirs. Verh. int. Ver. Limnol., 20: 1642-1646.

FRAILE, H., E. ORIVE, \& J. POZO. 1995. Evaluación del estado trófico y comparación de modelos relativos al fósforo en los embalses de Cernadilla y Valparaiso (río Tera, Zamora). Limnetica, 11: 29-38.

GAO, S., T.C. LUO, B. R. ZHANG, H. F. ZHANG, Y. W. HAN, Z. D. ZHAO, \& Y. K. HU. 1998.
Chemical composition of the continental crust as revealed by studies in East China. Geochim. Cosmochim. Acta, 62: 1959-1975.

GÓMEZ, N., J. L. RIERA, \& S. SABATER. 1995. Ecology and morphological variability of Aulacoseira granulata (Bacillariophyceae) in Spanish reservoirs. J.Plankton Res., 17: 1-16.

HEM, J. D. 1981. Rates of manganese oxidation in aqueous systems. Geochim. Cosmochim. Acta, 45: 1369-1374.

JAUME, D. 1991. The genus Diaphanosoma (Ctenopoda, Sididae) in Spain. Hydrobiologia, 225: 23-35.

JENSEN, H. S., P. KRISTENSEN, E. JEPPESEN, \& A. SKYTTHE. 1992. Iron/phosphorus ratio in surface sediment as an indicator of phosphate release from aerobic sediments in shallow lakes. Hydrobiologia, 235/236: 731-743.

LIJKLEMA, L. 1980. Interaction of ortophosphate with iron III and aluminum hydroxides. Environm. Sci. Technol., 14: 537541.

LÓPEZ, P. \& J. A. MORGUÍ. 1991. Efecto de la matriz mineral sobre la determinación de las fracciones de fósforo en sedimento. Actas del VI Congreso Español de Limnologia, Granada, España: 107-113.

LÓPEZ, P. \& J. A. MORGUÍ. 1993. Factors influencing fractional phosphorus composition in sediments of Spanish reservoirs. Hydrobiologia, 253: 73-82.

LÓPEZ, P. 2004. Spatial distribution of sedimentary $\mathrm{P}$ pools in a Mediterranean coastal lagoon 'Albufera d'Es Grau' (Minorca island, Spain). Mar. Geol., 203: 161-176.

LÓPEZ, P., X. LLUCH, M. VIDAL, \& J. A. MORGUÍ. 1996. Adsorption of phosphorus on sediments of the Balearic Islands Spain related to their composition. Estuar. Coast. Shelf Sci., 42: 185-196.

LYONS, T. W., J. P. WERNE, D. J. HOLLANDER, \& R. W. MURRAY. 2003. Contrasting sulfur geochemistry and $\mathrm{Fe} / \mathrm{Al}$ and $\mathrm{Mo} / \mathrm{Al}$ ratios across the last oxic-to-anoxic transition in the Cariaco Basin, Venezuela. Chem. Geol., 195: 131- 157.

MARGALEF, R., D. PLANAS, J. ARMENGOL, A. VIDAL, N. PRAT, A. GUISET, J. TOJA, \& M. ESTRADA. 1976. Limnology of the Spanish reservoirs. Vols. I \& II. . Madrid: Ministerio de Obras Públicas. $422+85$ pp.

MORGUÍ, J. A., R. QUILES, M. REAL, J. L. RIERA, P. LOPEZ, \& J. ARMENGOL. 1993. Sediment particle size patterns in Spanish reservoirs. Verh. int. Ver. Limnol., 25: 1210-1212. 
MURPHY, A. E., B. B. SAGEMAN, D. J. HOLLANDER, T. W. LYONS, \& C. E. BRETT. 2000. Black shale deposition and faunal overturn in the Devonian Appalachian basin: Clastic starvation, seasonal water-column mixing, and efficient biolimiting nutrient recycling. Paleoceanography, 15: 280-291.

NAVAS, A., B. L.VALERO-GARCES, \& J. MACHIN. 2004. An approach to integrated assesment of reservoir siltation: the Joaquin Costa reservoir as a case study. Hydrology and Earth System Sciences, 8: 1193-1199.

PALAU, A. 2003. Medidas de gestión y adecuación ambiental de embalses frente a la eutrofia. Limnetica, 22: 1-14.

POZO, J., E. ORIVE, H. FRAILE, \& A. BASAGUREN. 1997. Effects of the Cernadilla-Valparaiso reservoir system on the River Tera. Regulated Rivers-Research \& Management, 13: 57-73.

PRAT, N. \& M. V. DAROCA. 1983. Eutrophication processes in Spanish reservoirs as revealed by biological records in profundal sediments. Hydrobiologia, 103: 153-158.

REAL, M., M. RIERADEVALL, \& N. PRAT. 2000. Chironomus species (Diptera : Chironomidae) in the profundal benthos of Spanish reservoirs and lakes: factors affecting distribution patterns. Freshwat. Biol., 43: 1-18.

REAL, M., N. PRAT, \& J. L. RIERA. 1993. Abundance and distribution of profundal zoobenthos in Spanish reservoirs: differences between 1973/75 and 1987/88 surveys. Water Sci. Technol., 28 : 45-53.

RIERA, J. L., D. JAUME, J. DE MANUEL, J. A. MORGUI, \& J. ARMENGOL. 1992. Patterns of variation in the limnology of Spanish reservoirs: A regional Study. Limnetica, 8: 111-123.

RIERA, J. L., E. MARTI, J. A. MORGUI, F. SABATER, \& J. PEÑUELAS. 1995. Respiratory electron-transport system (ETS) activity in Spanish reservoirs - relationships with nutrients and seston. J. Plankton Res., 17: 513-530.

ROLLINSON, H. 1993. Using geochemical data. Evaluation, presentation, interpretation. Essex: Longman Scientific and Technical. $353 \mathrm{pp}$.

RUEDA, F., E. MORENO-OSTOS, \& J. ARMENGOL. 2006. The residence time of river water in reservoirs. Ecological Modelling, 191: 260-274.

SAGEMAN, B. B. \& T. W. LYONS. 2004. Geochemistry of fine-grained sediments and sedimentary rocks. In: Treatise on Geochemistry, vol 7. F. MacKenzie (ed.): 115-158. Elsevier Publ.

SIMEK, K., J. ARMENGOL, M. COMERMA, J. C. GARCIA, T. H. CHRZANOWSKI, J. NEDOMA,
\& V. STRASKRABOVA. 1998. Characteristics of protistan control of bacterial production in three reservoirs of different trophy. Internat. Rev. Hydrobiol., 83: 485-494.

SIMEK, K., K. JURGENS, J. NEDOMA, M. COMERMA, \& J. ARMENGOL. 2000. Ecological role and bacterial grazing of Halteria spp.: small freshwater oligotrichs as dominant pelagic ciliate bacterivores. Aquat. Microb. Ecol., 22: 43-56.

SOMOGYI, A., M. BRAUN, \& J. POSTA. 1997. Comparison between X-ray fluorescence and inductively coupled plasma atomic emission spectrometry in the analysis of sediment samples. Spectrochimica Acta Part B. Atomic Spectroscopy, 52: 2011-2017.

STUMM, W. \& J. J. MORGAN. 1981. Aquatic chemistry, $2^{\text {ond }}$ ed. New York : J. Wiley \& Sons. 780 pp.

TARDY, Y., V. BUSTILLO, \& J. L. BOEGLIN. 2004. Geochemistry applied to the watershed survey: hydrograph separation, erosion and soil dynamics: A case study: the basin of the Niger River, Africa. Applied Geochemistry, 19: 469-518.

TUNG, J. W. T. 2004. Determination of metal components in marine sediments using energy-dispersive X-ray fluorescence (ED-XRF) spectrometry. Annali di Chimica, 94: 837-846.

TUREKIAN, K. K. \& K. H. WEDEPOHL.1961. Distribution of the Elements in some major units of the Earth's crust. Geol. Soc. Am. Bull., 72: 175-192.

VALERO-GARCES, B. L., A. NAVAS, J. MACHIN, \& D. WALLING. 1999. Sediment sources and siltation in mountain reservoirs: a case study from the Central Spanish Pyrenees. Geomorphology, 28: 23-41.

VAN CAPPELLEN, P., E. VIOLLIER, A. ROYCHOUDHURY, L. CLARK, E. INGALL, K. LOWE, \& T. DICHRISTINA. 1998. Biogeochemical cycles of manganese and iron at the oxicanoxic transition of a stratified marine basin (Orca Basin, Gulf of Mexico). Environ. Sci. Technol., 32: 2931-2939.

VAN DER WEIJDEN, C. H. 2002. Pitfalls of normalization of marine geochemical data using a common divisor. Mar. Geol., 184: 167-187.

VERICAT, D. \& R. J. BATALLA. 2005. Sediment transport in a highly regulated fluvial system during two consecutive floods (lower Ebro River, NE Iberian Peninsula). Earth Surface Processes and Landforms, 30: 385-402.

VERSTRAETEN, G., J. POESEN, J. DE VENTE, \& X. KONINCKX. 2003. Sediment yield variability in Spain: a quantitative and semiqualitative analysis using reservoir sedimentation rates. Geomorphology, 50: 327-348. 
VIDAL, J., X. CASAMITJANA, J. COLOMER, \& T. SERRA. 2005. The internal wave field in Sau reservoir: Observation and modeling of a third vertical mode. Limnol. Oceanogr., 50: 1326-1333.

WEDEPOHL, K. H. 1995. The composition of the continental crust. Geochim. Cosmochim. Acta, 59: 1217-1239.
WERNE, J. P., B. B. SAGEMAN, T. W. LYONS, \& D. J. HOLLANDER. 2002. An integrated assessment of a "type euxinic" deposit: evidence from multiple controls on black shale deposition in the Middle Devonian Oatka Creek Formation. Am. J. Sci., 302: 110- 143 . 